\title{
白馬岳高山帯「節理岩」における植生遷移と斜面発達
}

\author{
小泉 武 栄*
}

\section{Alpine Plant Succession on Granite-porphyry Rubble Slopes of Mt. Shirouma, the Northern Japanese Alps, in Relation to Slope Development}

Takeei KOIZUMI*

\begin{abstract}
In the alpine zone of the Japanese Alps, distributions of alpine plant communities are closely related to lithology. There are clear contrasts among the combinations of vegetation and lithology. However, the author found that several different plant communities often occur in areas of the same lithology. In a wind-exposed rubble slope on granite-porphyry area of Mt. Shirouma, three kinds of plant communities were distinguished: sparse lichen community, lichen and moss community, and wind-exposed herb-heath community partly covered with Pinus pumila scrub. These communities are believed to be in different serial stages of succession. To clarify the cause of this distribution, the age of angular debris production on the slope was examined. Weathering rind thickness in angular rock fragments on rubble slope was used to speculate the age of debris production. Debris covered with sparse lichen was produced during the Neoglaciation period $(2,000-3,500 \mathrm{y}$. BP), while debris covered with lichen and moss was formed in the late Glacial period $(10,000-11,000 \mathrm{y}$. BP). In the area covered with wind-exposed herb-heath and Pinus pumila scrub, the debris were produced in the Last Glacial Period. These ages mean the time costed for the plant succession on these rubble fields. It seems to be necessary 3,000 years for settling the sparse lichen community, about 10,000 years for the lichen and moss community, and more than 10,000 years for the wind-exposed herb-heath and Pinus pumila scrub community. The progress of succession is extremly slow in the area of this lithology, because fine matrix which is important for seed germination and root extention is lacking in these rubble slopes, in addition to severe climatic conditions in winter.
\end{abstract}

\section{I. はじめに}

日本アルプスの高山帯強風地では, 植物群落の 分布は地質と密接に関連しており，地質が変わる と植物群落も劇的に変化することが少なくない (口絵 2-1，2)。これは, 斜面上の岩屑の粒度組成 や安定度, あるいは岩屑の生産性が, 地質によっ
て大きく異なっているためである。たとえば，現 在, 細か、岩原の生産・移動が活発に行なわれて いる流紋岩地域や安山岩地域では, 斜面物質の不 安定さを反映して，コマクサやタカネスミレから なる高山荒原植物群落が成立しており, 逆に表層 の岩屑が安定している花崗斑岩地域や砂岩・頁岩 地域では，風衝矮低木群落や風衝草原が分布する

\footnotetext{
* 東京学芸大学地理学研究室

* Department of Geography, Tokyo Gakugei University
} 
ことが多い。このことはすでに何回かに分けて報 告した (小泉, 1979, 1980ほか)。

またこれとは別に，地質によって斜面の形成期 が異なることがあり，それが斜面上の植物群落の 発達にお扮きな影響を与えている事例も報告した (小泉，1989)。たとえば，北アルプス薬師岳の高 山帯強風地においては, 次のようである。まず石 英安山岩地域では，ネオグラシェーション期に形 成された，ほぼ無植生の砂礫地が広い面積を占め る。しかし石英斑岩地域では晚水期に形成された 岩塊斜面が斜面の大半をおおい，そこには地衣類 と蘚苔類のみが分布している。一方, 現在わずか に岩綗の生産のみられる石英安山岩地域の一部に は, タカネスミレ群落とイワスゲ群落がみられる が，その分布はごく狭い(小泉，1989）。

このように，植生分布に対する地質の影響はお おきいが，その後，同一の地質地域でも，成立す る植物群落に明瞭な違いのあることがいくつかの 地域で見出され, 問題はもう少し複雑であること が明らかになってきた。たとえば口絵 2-3に示し たものは，北アルプス鉢ケ岳の高山帯強風地にあ る花崗斑岩地の一部を写したものであるが，ここ では植物群落のよく発達した礫地の上に, 上方か ら移動してきた新しい砂が乗っており，後者の部 分の植被は明らかに乏しい。また，北アルプス三 ツ岳の高山植物群落の分布を調べた水野（1989） は，同一の地質地域にいくつかの植物群落が生じ 得ることを示し, 植物群落の分布には表層岩屑の 粒度組成, とくにマトリックスの有無が重要な役 割を果たしているとした。ただ水野は同一の地質 地域でも粒度組成が大きく異なる場合のあること を強調したが，同じ地質の中でなぜ異なった粒度 組成の場が生じ,なぜマトリックスのある場所と ない場所が生ずるのかといった点についてはそ の原因を明らかにしなかった。

筆者は今回, 白馬岳北方の調査地で, 同一の地 質地域にありながら，斜面をお抢う岩屑の供給期 に違いがあるために異なった植物群落が発達する, という新しい事例を見出したので報告する。岩屑 斜面の形成年代の推定には, 岩屑表面に生じた風 化被膜の厚さを用い，年代を異にする斜面に成立
した植物群落の構成から, 遷移の系列と高山帯に おりる植生遷移に要する時間を推定することがで きた。

本研究の現地調査にあたり, 東京学芸大学自然 地理ゼミの沢辺朋史, 関 秀明, 青柳章一, 和気 智宏，大宮 剛，赤松直子，酒井 啓，日比野経 子, 清水俊文, 真崎 庸の諸君に多大なご協力を いただいた。また資料の統計処理には同じくゼミ OB の青木賢人君の手を煩わせた。以上の諸君に 厚くお礼申し上げる次第である。

\section{II. 花崗斑岩地「節理岩」とその植物群落}

\section{1）調査地域について}

北アルプス白馬岳の北方には，三国境と呼ばれ ている顕著な肩がある。ここは主稜線から派生し て，東の小蓮華山方面にのびる大きな支尾根の分 岐点にも当たっているが，ここから北へのびる主 稜線の肩の部分に，筆者らが「節理岩」と仮称し ている柱状節理の発達するトアがある（図 1)。 今回の調查地域は, この節理岩を中心とする一带 である(口絵 2-4)。

節理岩のある尾根のでっぱりは，海抜およそ $2,590 \mathrm{~m}$ 。三国境からはほぼ真北に当たり，直線 距離にして拉よそ $700 \mathrm{~m}$ 離れている。一帯は尾 根ののびる方向（北北西一南南東方向）に線状凹 地が何本も走り，低い尾根と浅く丸い谷が交替す る特異な地形を形づくる。節理岩はそのうち西か ら数えて 2 番目の尾根上に位置している。節理岩 のある尾根は小規模ながら非対称山稜を形つくくり, 西側は相対的になだらかな斜面をつくるが，東側 は急崖をなし，夏まで雪田の残る小さな雪食凹地 に続いている。節理岩のトアは比高 $3 \mathrm{~m}$ ほどで, 地質は花崗斑岩からなる。

口絵 2-4 に示したように，節理岩のすぐ南には， 高山地形研究グループ (1978) や小泉 (1979), 相 馬ほか（1979），岩田（1980）などが，周水河性 の砂礫の移動速度を調べた平滑斜面がある。この 斜面をつくるのは白色の流紋岩礫で，上に凸のな だらかな砂砂地を形成している。砂礫地の植物は コマクサとタカネスミレが数パーセントの被度で 生育するだけで，ほとんど無植生に近い。そのた 


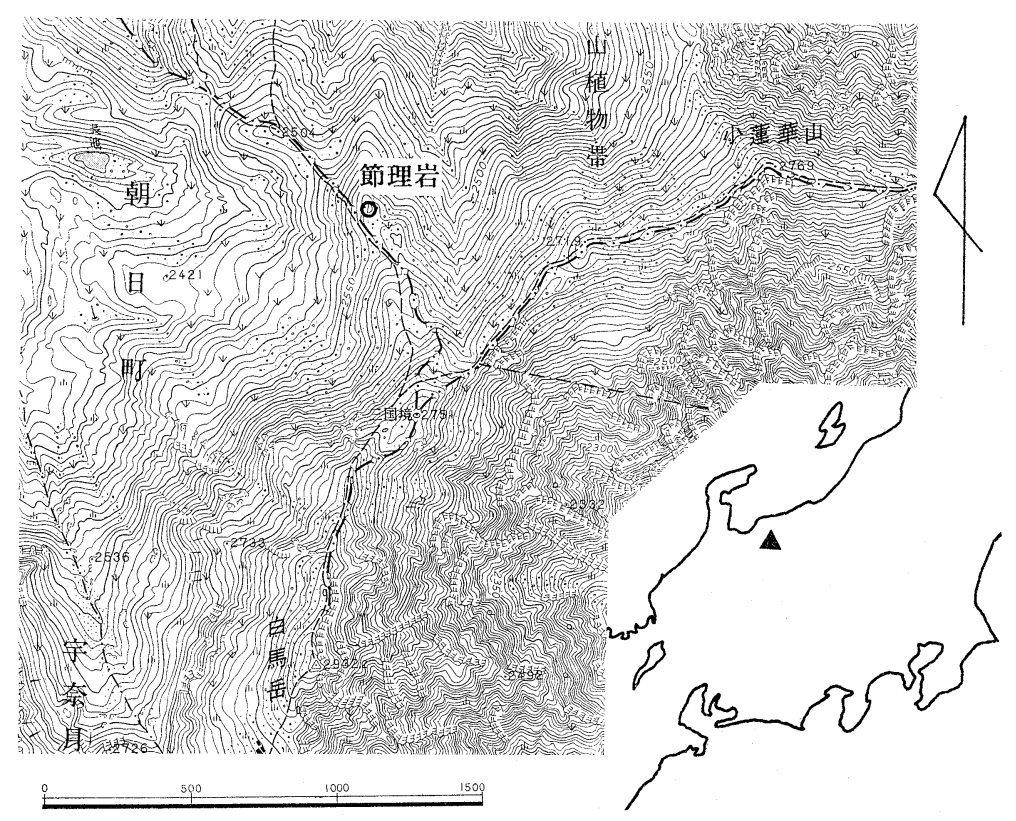

図 1 調查地域の位置

○をつけたところが節理岩.

めここは一見，残雪に見間違えるような，白く輝 く斜面となっている。しかしその表面にはみごと な条線土がみられ，活発な周水河作用が存在する ことを示している。

この流紋岩砂碩地の北側には, 古生界の輝緑岩 からなる小ピークがあり，そこには風衝草原が発 達する。そしてそのさらに北側が節理岩のある花 崗斑岩地域である。

節理岩のある高まりは，いわば稜線の肩に生じ た小さなでっぱりで，その高まりの頂上からは西 南方向にのびる小さな支稜があり（図 2 ），その 先端が柱状節理のある節理岩となっている。節理 岩の北方と下方には, 高まりの上部で生産された 岩砂が移動してできた, 風あたりの強い礫地が発 達する。礫地のある斜面はほぼ西向きで, 傾斜は およそ $32^{\circ}$ である。以下では節理岩付近の調査地 域を「節理岩地域」と総称する。また以下では, 植被の有無にかかわらず，マトリックスを欠く礫 地を「硆地」，砂質・泥質のマトリックスに富む 礫地を「砂砂地」と，それぞれ呼ぶことにする。

\section{2）節理岩地域の植物群落の分布}

節理岩地域の西向き斜面は，遠目には植被がよ
く発達しているようにみえる。しかし現地で観察 すると, 植被の発達するのは南側の半分だけで, 北半分は無植生に近い磁地が占める。また南側の 半分もさらに，植被がほぼ全面をおおう部分と， 八イマツなどの植被地が点在する部分とに分かれ ている。筆者らは，植被の分布状況を正確に把握 するために，現地測量により原縮尺で200分の 1 の地形図を作成し，そこに植生の分布を記入した (図 2 )。以下，植生分布の概略を述べる。

まず節理岩の直下では，マトリックスを欠く礫 地をおおって風衝矮低木群落と風衝草原の混合群 落が卓越し, 植被は露岩地を除いて碩地のほぼ全 面をお抢う。この群落中には八イマツの団塊が点 在し，節理岩から斜面長にして $20 \mathrm{~m}$ 余り下方で 丈の低いハイマツ群落に移行していく。砅は長径 が50〜 60 cm の粗大なものが多く，礫間を 10〜30 $\mathrm{cm}$ の砂が充填している。以下では，この植被の よく発達した礫地を磁地栭と仮称する（口絵 2-8）。

碟地而の南側には，流紋岩質の細かい砂礫から なるローブ状の高まりがあり，䃯地IIII植被の分 布はそこでとぎれている。

一方, 調查地域の北半部では, 風衝矮低木群落 


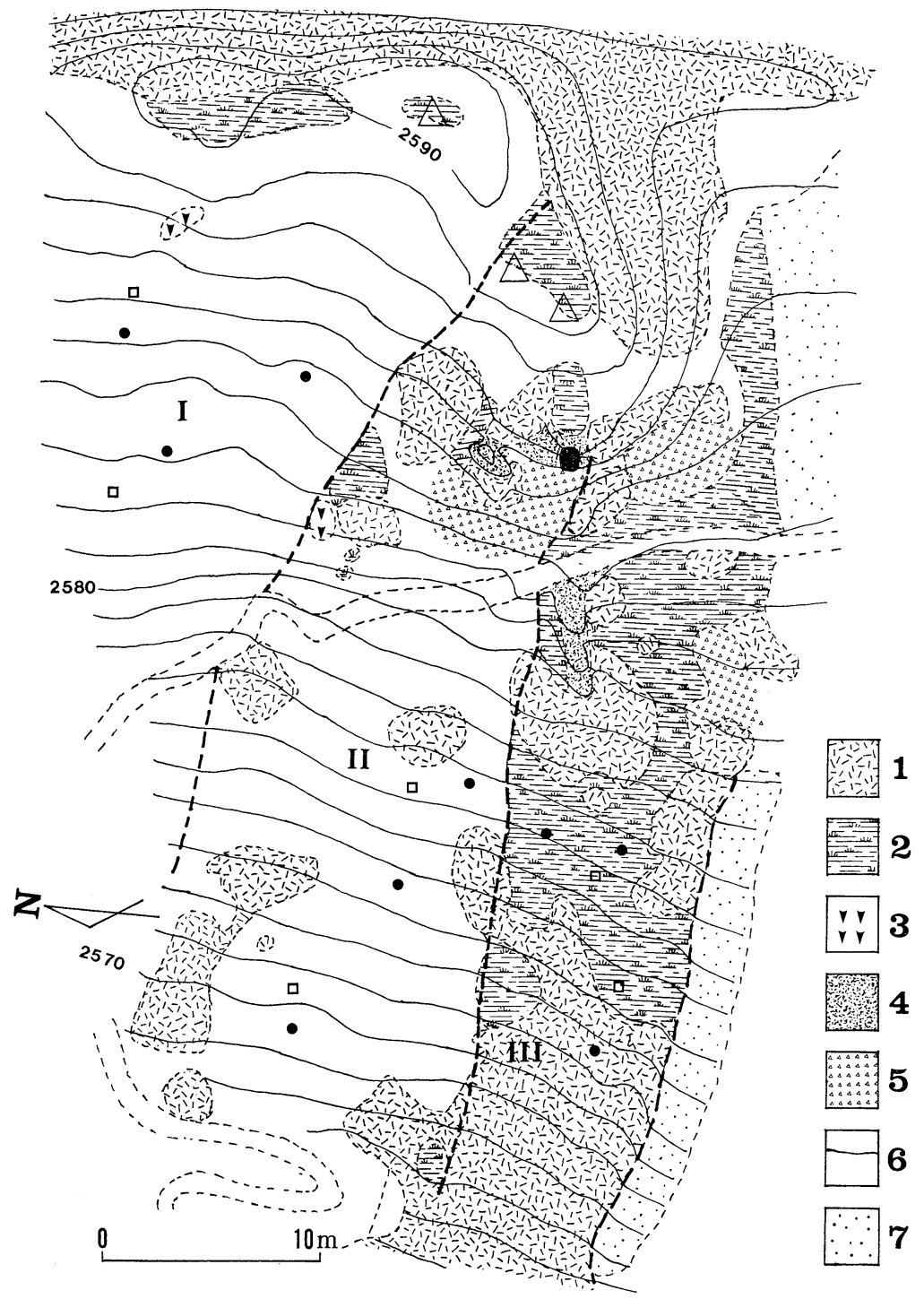

図 2 節理岩地域の地形々植生分布

等高線は $1 \mathrm{~m}$ 間隔. 標高はおよその值を示す. 黒く塗りつぶした部分が節理岩.

1. 八イマツ低木林, 2. 風衝草原と風衝矮低木群落の混合群落, 3. コマクサ群落, 4. 露岩

地, 5. 巨礫の集積, 6. 高等植物を欠く礫地, 7. 砂砂地

○: 植生調查地点, $\square:$ 風化被膜調査地点, $\Delta:$ 小ピーク

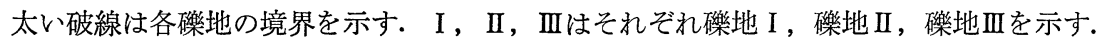

の分布するでっぱりの頂部を除き，一見したとこ ろまったく無植生の砂地が広がる。礫は長径20 $30 \mathrm{~cm}$ のものが卓越している（図 3 )。この礫地 は高等植物をまったく欠いており, 礫間や砂の表 面にのみ地衣類がわずかに分布している（口絵 2-5，6)。図 2 の左側上部にコマクサが数個体分
布するのが示されているが，これは表層の礫が局 部的に滑落して生じた窪みに出現したもので, 例 外はそれだけである。以下では，この地衣類のみ が分布する礫地を，砂地 I と仮称する。

砅地 I と礫地IIIの閒には，ハイマッや風衝矮低 木群落の点在する礫地がある。卓越粒径は 30 50 

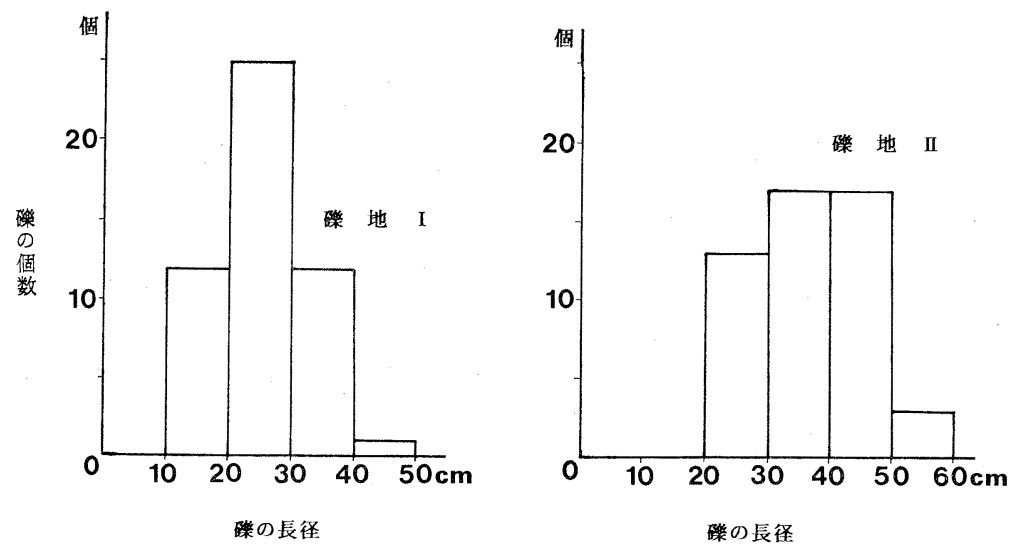

図 3 各碟地の構成礫の大きさの頻度分布

横軸 : 砶の長軸の大きさ, 縦軸 : 䃯の個数

なお，礫地而については植被を破壞する恐れがあったため調查しなかった.

表 1 各礫地の性質とそこに成立した植物群落の特色

\begin{tabular}{|c|c|c|c|}
\hline & 分 & 斜面堆積物の特色 & 植物 群 落の特色 \\
\hline 礫地 I & 調查地域の北半部 & $\begin{array}{l}\text { 径 } 20 \sim 30 \mathrm{~cm} \text { の新鮮な角礫 } \\
\text { マトリックスを欠く }\end{array}$ & $\begin{array}{l}\text { 磁閒や礫の表面に地衣類が疎らに付着 } \\
\text { 局部的にコマクサが分布 }\end{array}$ \\
\hline 礫地 II & 礫地 I とIIIの間 & $\begin{array}{l}\text { 径 30 } 50 \mathrm{~cm} \text { の風化の進んだ角礫 } \\
\text { 礫の表面は黒む゙んでいる } \\
\text { マトリックスを欠く }\end{array}$ & $\begin{array}{l}\text { 地衣類に加え, 礫間に蘚苔類が多数現わ } \\
\text { れる } \\
\text { 一部にハイマツや風衝矮低木群落が分布 }\end{array}$ \\
\hline 礫地III & 節理岩の直下 & $\begin{array}{l}\text { 径 } 50 \text { ～} 60 \mathrm{~cm} \text { の風化の進んだ角礫 } \\
\text { の間を手の平大の礫が充填 } \\
\text { マトリックスは欠如しているが, } \\
\text { 礫層の表層に薄い高山草原土壤 } \\
\text { がある }\end{array}$ & $\begin{array}{l}\text { 風衝矮低木群落と風衝草原の混合群落が } \\
\text { 成立 } \\
\text { 斜面下部ではハイマツ群落に移行する }\end{array}$ \\
\hline
\end{tabular}

$\mathrm{cm}$ である（図 3 ）。この䃯地も高等植物をほぼ 欠いているが，礫地 I に比べると黒ずんでみえ， 䃯の風化も進んでいる（口絵 2-7）。ただしこの礫 地ではよく観察すると，地衣類に加え，礫閒に相 当数の蘚苔類の存在することがわかる。しかし一 見すると無植生にみえるから，䃯地III との境目は きわめて明瞭である（口絵 2-9）。以下，この黒ず んだ色の礫地を礫地 II と仮称する。

以上のよ5に，同一の地質地域にありながら， 各礫地の性質とそこに成立した植物群落の間には 著しい違いが認められる。その違いを表 1 にまと めて示した。

\section{3）各群落の組成}

次に，各群落の組成を知るために，3つの礫地
表 2 各碩地に分布する地衣類, 蘚苔類と 高等植物の種数

\begin{tabular}{c|ccc}
\hline & 地 衣 類 & 蘚 苔 類 & 高等植物 \\
\hline 礫地 I & 12 & 1 & $(1)$ \\
礫地 II & 21 & 4 & $(6)$ \\
礫地 III & 15 & 3 & 21 \\
\hline
\end{tabular}

（ ）内の数字はごく一部にのみ出現するものを示す.

に調查枠を設置し，その枠内における地衣類，蘚 苔類，高等植物の出現種数を調べた。結果を表 2 に示す。まず礫地 I では地衣類が 12 種出現し（こ の中には礫の表面にペンキ状に付着した地衣類が 6 種含まれるが，種名の同定は困難である），蘚 苔類が 1 種分布する。しかし高等植物は，まった 
表 3 礫地而における植物群落の組成

\begin{tabular}{|c|c|c|c|}
\hline 種 & 地点(1) & (2) & (3) \\
\hline Pinus pumila ハイマツ & & & $90 \%$ \\
\hline $\begin{array}{l}\text { Empetrum nigrum var. japonicum } \\
\text { ガンコウラン }\end{array}$ & & & 25 \\
\hline Vaccinium vitis-idaea コケモモ & & + & 15 \\
\hline Vaccinium uliginosum クロマメノキ & 30 & 35 & \\
\hline Arctous alpinus ウラシマツッジ & 15 & 5 & 5 \\
\hline $\begin{array}{l}\text { Geum calthaefolium var. nipponicum } \\
\text { ミヤマダイコンソウ }\end{array}$ & 12 & 7 & \\
\hline Carex stenantha イワスゲ & 3 & 5 & \\
\hline Potentilla matsumurae ミヤマキンバイ & 3 & 4 & \\
\hline Calamagrostis nana ヒナノガリヤス & 4 & 2 & \\
\hline Kobresia bellardii ヒゲハリスゲ & 4 & + & \\
\hline Arcterica nana コメバツガザクラ & 1 & 2 & 1 \\
\hline $\begin{array}{l}\text { Festuca ovina var. alpina } \\
\text { グサミヤマウシノケ }\end{array}$ & 1 & 2 & \\
\hline Euphrasia insignis ミヤマコゴメグサ & 1 & 1 & \\
\hline $\begin{array}{l}\text { Oxytropis nigrescens var. japonica } \\
\text { オヤマノエンドウ }\end{array}$ & 1 & + & \\
\hline Campanula chamissonis チシマギキョウ & 1 & & \\
\hline Lagotis glauca ウルップソウ & + & & \\
\hline Hierochloe alpina タカネコウボウ & & + & \\
\hline $\begin{array}{l}\text { Carex subumbellata var. verecunda } \\
\text { クモマシバスゲ }\end{array}$ & + & & \\
\hline Gentiana algida トウヤクリンドウ & + & & \\
\hline Vaccinium smalli オオバスノキ & & & + \\
\hline Lycopodium obscurum マンネンスギ & & & 6 \\
\hline 植＼cjkstart被＼cjkstart率 & 70 & 60 & $90 \%$ \\
\hline 出 現 種 数 & 15 & 13 & 6 \\
\hline 斜 面 の 向 き & 西北西 & 西北西 & 西 \\
\hline 傾 斜 & $27^{\circ}$ & $28^{\circ}$ & $28^{\circ}$ \\
\hline
\end{tabular}

く出現しない（わずかな例外として，さきほど述 べたコマクサ数個体がある。表 2 ではカッコに入 れて示した)。

一方, 礫地II では地衣類は 21 種類に達し（ここ でも 8 種のペンキ状の地衣を含む), 他に蘚苔類 が 4 種出現する。高等植物は八イマツのほか, ク ロマメノキ，ミヤマキンバイ，タカネスズメノヒ エといった風衝矮低木群落の要素 4 種と, タカネ スミレが一部に島をつくって分布するが, 分布域 がごく限られるので, 表 2 ではやはりカッコに入 れて示してある。
礫地IIIでは地衣類は15種に減少し，代わって高 等植物が 21 種現われて，斜面上を60〜 70\%の被度 でおおう（表 3 ）。主な出現種はクロマメノキ, ミヤマダイコンソウ, ウラシマッッジ，ヒナノガ リヤス，ヒゲハリスゲなどである。

表 4 には各礫地に分布する主な地衣類と蘚苔類 を示した。礫地 I ではチズゴケやイワザクロゴケ が出現するのに対し, 䃯地II ではムシゴケやオニ ハナゴケモドキ，クロゴケ，ヒジキゴケなどが卓 越する。礫地IIIではエイランタイ類やミヤマハナ ゴケ類，ハイキンモウゴケなどが優勢になる。 
表 4 各碟地に分布する主要な地衣類と蘚苔類

\begin{tabular}{|c|c|c|c|}
\hline & 礫 地 I & 䋶 地 II & 䃯 地 III \\
\hline 地衣類 & $\begin{array}{l}\text { Anaptychia microphylla } \\
\text { チデミウラジロゲジゲジゴケ } \\
\text { Haematomma lapponicum } \\
\text { イワザグロゴケ } \\
\text { Rhizocarpon geographicum } \\
\text { チズゴケ } \\
\text { Parmelia incurva } \\
\text { イリタマゴゴケ } \\
\text { Cladonia verticillata } \\
\text { オオバハナゴケ }\end{array}$ & $\begin{array}{l}\text { Cladonia pseudostellata } \\
\text { オニハナゴケモドキ } \\
\text { Rhizocarpon geographicum } \\
\text { チズゴケ } \\
\text { Thamnolia vermicularis } \\
\text { ムシゴケ } \\
\text { Cladonia } \text { sp. } \\
\text { ヘナゴケ属 } \\
\text { Umbillicaria } \text { sp. } \\
\text { イワタケ属 } \\
\text { Palmelia } \text { sp. } \\
\text { ウメノギケ属 }\end{array}$ & $\begin{array}{l}\text { Cetraria cucullata } \\
\text { ウスキエイランタイ } \\
\text { Cetraria ericetrum } \\
\text { マキバエイランタイ } \\
\text { Cladonia speudevansii } \\
\text { ウスイロミヤマハナゴケ } \\
\text { Cladonia merochlorophaea } \\
\text { メロジョウゴゴケ } \\
\text { Thamnolia vermicularis } \\
\text { ムシゴケ } \\
\text { Cetraria sp. } \\
\text { エイランタイ属 }\end{array}$ \\
\hline 蘚苔類 & & $\begin{array}{l}\text { Andreaea rupestris var. } \\
\text { fauriei クロゴケ } \\
\text { Hedwigia ciliata } \\
\text { ヒジキゴケ }\end{array}$ & $\begin{array}{l}\text { Ulota reptans } \\
\text { ハイキンモウゴケ } \\
\text { Polytrichum juniperinum } \\
\text { スギゴケ }\end{array}$ \\
\hline
\end{tabular}

なお，各砂地における地衣類や蘚苔類の被度に も肉眼での観察では大きな差があるが, 羱の表面 にペンキ状に付着する種があるため，それを数值 で表現することは不可能である。口絵でその違い をみていただきたい。

以上で述べたように，3つの礫地に成立した植 物群落には顕著な違いが認められる。しかしそれ にもかかわらず，3つの礫地の性格にははっきり とした違いはみられない。たとえば, 䍴地而には 薄い乾性型の高山草原土鎧ができているものの, 土壤母材となる礫地はいずれもマトリックスを欠 いており，水野（1989）が三ツ岳から報告したよ らにマトリックスの有無が植生分布を支配してい るとは考えられない。また礫地IIIで群落の発達の よい理由を土壤層の存在に求めるならば, 礫地 I , II になぜ土壤が発達しないのかを逆に説明しなけ ればならない。

礫径は, 砂地 I と䃯地 II に比べ, 礫地III ではや や大きめである。しかし各礫地の礫は，コマクサ の出現する数地点を除いてほぼ安定しており, 䃋 径の違いでも，上記のような植物群落の著しい違 いを説明することはできない。したがって先述の 出現種数の違いは, 粒径の違いやマトリックスの
有無などを反映したものではなく，何か別の条件 の違いによるものだろうと考えられる。

気候条件に関しても，礫地 I と礫地II， IIIでは 尾根に近い部分とやや下がった部分という違いは あるが，いずれも強風地に位置しているから，先 述の植被の違いを説明するのは難しい。とくに礫 地 II とIIIには，気候条件の差はほとんどない。

そこで斜面上の礫を改めて観察すると, 礫地 I では礫がまだ新鮮な感じを与え，角も鋭いのに， 礫地II， III では砂の風化が進み, 礫表面もボロボ ロになっていて鉱物粒子が碷の表面から突出して いるといら違いが認められる。このことは，斜面 上の砂の供給期に違いがあって，それが各礫地の 植物群落の違いをもたらしたのではないかという ことを予想させる。

\section{III. 植物群落の成立条件と成立過程に関す る考察}

\section{1）各繰地における岩屑の供給期}

上の予想を検証するために，次に岩屑の表面に 生じた風化皮膜を用いて，それぞれの礫地をつく る岩原の供給期を推定しょうと考えた。風化皮膜 の調查は，小泉・青柳（1993）の示した方法に従 

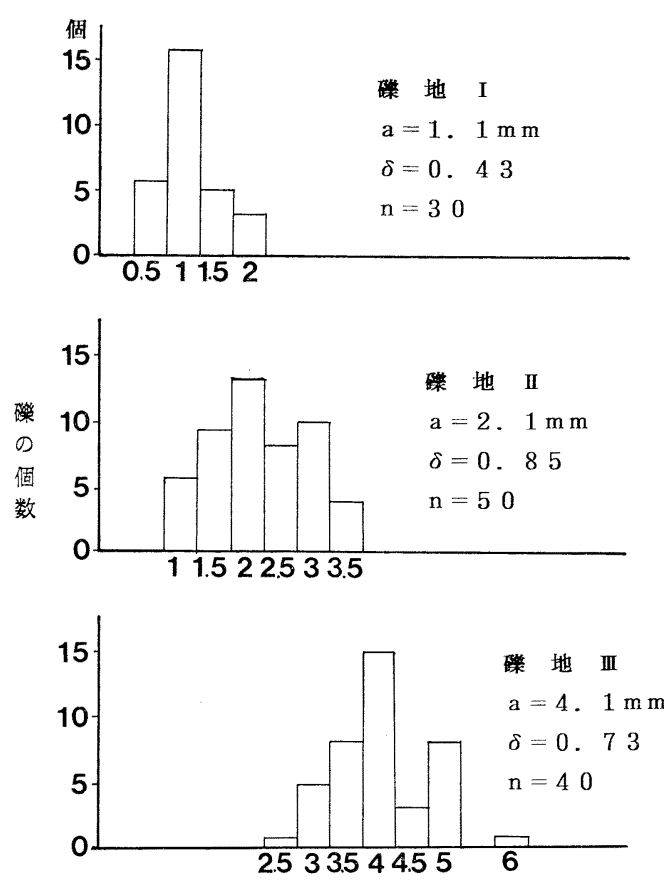

風化被膜の隄さ $(\mathrm{m} \mathrm{m})$

図 4 各礫地の岩屑に生じた風化被膜の厚さの頻度 分布

横軸 : 風化被膜の厚さ, 縦軸 : 砂の個数 $\mathrm{a}$ : 風化被膜の厚さの平均值, $\delta$ : 標準偏差, $\mathrm{n}$ : 調査個数

い，各砅地に置いた $2 \mathrm{~m} \times 2 \mathrm{~m}$ の枠（枠の位置は 図 2 に示した）からランダムに礫30〜 50個を取り 出し, 風化皮膜の厚さを $0.5 \mathrm{~mm}$ 刻みで計測した。 その結果, 図 4 に示したよらなグラフが得られた。 風化皮膜の厚さは䃯地 $\mathrm{I}$ で平均 $1.1 \mathrm{~mm}$, 礫地 II で2.1 mm, 䃯地III で $4.1 \mathrm{~mm}$ である。なお䃯地 I 〜 IIIで得られた標本について， $\mathrm{t}$ 検定を用いて平 均值の差を検定したところ, 有意水準 $5 \%$ で有意 であることが確認された。したがって礫地 I 〜 III の形成期は有意に異なると考えられる。

ところで, このような風化皮膜の厚さから堆積 物の絶対年代を決めるためには, あらかじめ目的 とする岩石にっいて, 経過した年代によってどれ だけ風化皮膜の厚さが増加するかを示す，風化皮 膜の成長曲線を描いておかなければならない。っ まりこのスタンダードとなる值と比較することに よって, 初めて年代未知の岩原の供給された年代 の推定が可能になるのである。だからそのために
は，年代の確定したモレーンや，埋没腐植層など によって年代を確定できる堆積物を見出し，その 構成礫に生じた風化皮膜の厚さを調べてスタンダ ードを確立する必要がある。

しかしながら白馬岳付近では, 花崗斑岩の分布 域はごく狭く, 周辺のカールなどで花崗斑岩碟を 含むモレーンの堆積物を見出すことは困難である。 また埋没腐植層も今のところ, 花崗斑岩地域から は見出されていない。したがって当面, 花崗斑岩 地域では風化皮膜の成長曲線を描くことは困難で ある。

そこで本研究では次善の策として, 他の岩石に 生じた風化皮膜の成長曲線を援用して, 斜面上の 岩屑の供給年代を推定することにした。

北アルプス薬師岳高山帯の西側斜面には, 石英 斑岩といら花崗斑岩に鉱物組成のよく似た岩石が 分布し，そこでの調査によれば，石英斑岩礫に生 じた風化皮膜の厚さは，およそ2,000 3,500年前 のネオグラシエーション期のものが $0.8 \mathrm{~mm}, 1$ 万年前の晚水期のものが $2.4 \mathrm{~mm}, 2$ 万年前の 最 終水期最盛期の生産と推定されたものが $4.0 \sim 4.4$ $\mathrm{mm}$ であった。さらに $4 \sim 5$ 万年前の最終水期前 半の寒冷期に供給されたものが， $7.8 \sim 8.0 \mathrm{~mm}$ という值を示した（小泉・青柳，1993）。薬師岳に おける年代の推定は, 東側斜面の金作谷カールに 残された新旧のモレーンとの対比から得られたも のである。また岩石の性質は異なるが, 白馬岳北 方・長池周辺の流紋岩砂地では, ネオグラシエー ション期に生産されたと推定される礫が, 厚さ $1.0 \mathrm{~mm}$ の風化皮膜をもっていた（小泉・関, 1988)。

これらの值と本地域で得られた值とを比較する と, 本地域の䃯地 I の岩屑供給期はネオグラシエ ーション期に, 磉地 II のそれは晚水期に, 磷地III のそれは最終水期最盛期にそれぞれ対応させるの が適当であると考える。

なお，ここで示した各磁地における岩屑供給の 年代については, 将来, 風化被膜の発達について の研究の進展によって訂正される可能性も存在す る。しかし現時点ではこう推定するのがもっとも 適切であると考える。 


\section{2）節理岩地域における植物群落の成立過程}

以上のような推定に基づいて，節理岩地域の高 山帯強風地での斜面発達を加味しながら植物群落 の成立過程を考えてみると，次のようになろう。

まず 2 万年ほど前の最終水期最盛期には，稜線 部一帯から䃯の供給があり, 節理岩地域全域にわ たって広、岩晚斜面が形成されたと考えられる。 この広、岩屑斜面のらち, 当時のまま現在に至っ たのが礫地IIIであろう。ここでは約 2 万年の歳月 の間に䃯の風化が進み, 土壤層も発達してきて, そこに風衝矮低木群落・風衝草原の混合群落と八 イマツ群落が成立した。また植被は礫地のほぼ全 面をおおうまでに発達した。土壤物質の供給源と しては, 礫の風化による鉱物粒子の供給や植物が 分解してできた腐植の供給のほか, 水河堆積物起 源のレス，それに火山灰も含まれていると考えら れる。

ところが 1 万年ほど前の晚水期に，節理岩地域 の北半部では気候の寒冷化によって稜線部からあ らたな礫の供給があり，礫地 I と礫地 II の一帯を お扝った。当時，抢そらく礫地 I と砂地 II の領域 にも何らかの植物群落が成立していたと推定でき るが，それらは新たに移動してきた礫によって埋 められてしまったと考えられる。この新しい䃯地 の名残が礫地 II で，ここではその後 1 万年ほどの 年月の間に，ようやく地衣類と蘚苔類が砂間を埋 め, 一部には八イマツや風衝矮低木群落が入り込 むまでに植生が回復したとみられる。これが礫地 II に現在分布している植物群落であろう。

一方， 3,000年ほど前のネオグラシエーション 期には，さらに新しい岩屑の供給があり，稜線部 から供給された岩㞒が移動して礫地 I の部分をお おった。そのため礫地 I では古い植物群落は岩觔 に埋められて滅び, 植生遷移は振出しに戻って, ふたたび，まったく無植生の䃇地からスタートせ ざるを得なかった。そしてその後, 約 3,000 年が 経過し，礫の表面や礫間にようやくチズゴケなど の地衣類が生育するようになった。これが礫地 I の現在の姿であろら。礫地 II と III の部分はこの新 しい岩屑による埋没からは免れることができたた め, 古い植物群が保存されたとみられる。
以上のように，節理岩地域に分布する 3 つのタ イプの植物群落は, 最初に予想した通り，それぞ れの岩屑斜面が形成されてから経過した時間の差 を反映したものであると考えることができる。

なお節理岩地域という同一の場所にありながら， それぞれの岩肩供給期に岩屑のおおった範囲が異 なるのは，稜線部において岩屑を生産する場所が 時代が新しくなるにつれてしだいに縮小してきた ためだと考えられる。稜線部に露出する岩石の破 砕が進んでいるために，それぞれの場所の節理密 度をデータで示すことはできないが，稜線部の岩 石に生じた節理に粗密があり，それが原因となっ た可能性が強い。つまり氷河時代には節理岩一带 のすべての節理が凍結破砕作用によって開口し， 岩屑を生産したが，寒冷の度合いがやや弱まった 晚水期には節理の粗い部分からの礫生産はもはや 起こらなくなり，寒冷の程度がさらに弱くなった ネオグラシエーション期には，岩桷の生産は細か い節理の入った部分だけに限られるようになった， と考えられるのである。礫地IIIをお拉う礫が50～ $60 \mathrm{~cm}$ 程度と大き目なのに, 䃯地II, 䃯地 I と礫 地の形成が新しくなるにつれて，礫径がしだいに 小さくなる傾向が認められるのも，このことを裏 ゔけるものであろう。

\section{3）節理岩地域における植生遷移について}

各碩地に成立した植物群落は，見方をかえれば， 植生遷移の初期段階から極相植物群落に発達して いく各ステージを示しているとみることもできる。 そこで，これまでの話をもとに，節理岩の花崗斑 岩地での植生遷移の進行とそれに要する時間を推 定してみると，次のようになる。

節理岩地域は高山带の強風地に位置するが，こ この礫地でほまず 3,000 年ほどかかって疎らな地 衣類からなる群落, 数千年から 1 万年程度かかっ て地衣類と蘚苔類の混合した群落ができる。そし てさらに数千年かかってようやくハイマツ群落や, 風衝矮低木群落・風衝草原といった群落ができる ことになる。

遷移の進行状況は, 基本的に植物生態学の教科 書に紹介されている通りといってよく，まず岩屑 の表面や隙間に地衣類が生育し始め, ついでそれ 
を足がかりにして鯖苔類が侵入する。そして時間 の経過とともに岩屑の風化が進んで, しだいに細 かい斜面物質や土壤が集積し，ついにはそこに高 等植物からなる強風地の植物群落ができる，とい うものである。この最後の時期には草原土壤が発 達し, 地衣類や蘚苔類は高等植物に場を譲り, 種 類数も減少してしまう。

\section{4）植生遷移と礫層のマトリックス}

ところで上で示した遷移に要する時間は, 極地 や世界各地の高山などから報告された植生遷移に 要する時間に比べると, きわめて大きいものとな っている。たとえば，水野（1994）が紹介したア フリカのケニヤ山では, 小水期の終了に伴う山岳 氷河の縮小を追いかけるようにして, 植被が回復 しつつあるという。スカンジナビア山脈で，小水 期以降の水河の後退に伴う植生の回復状況につい て大部の報告を書いた Matthews（1992）も，モ レーン上では 300 年程度で植被が回復するとして いる。また筆者自身，ヨーロッパアルプスのオー バーグルグルの山地で150 200年ほど前の小水期 に形成されたモレーン上に，すでに先駆植物が侵 入しつつあるのを観察したことがある。

これらの值に比べると, 本地域で得られた年代 值は 2 桁も大きいものであり, 日本生態学会や横 浜で開催された国際生態学会での発表の折なども, この点に関して多数の疑問が寄せられた。このよ らに植生遷移に時間のかかる理由として，筆者は 節理岩地域の礫地におけるマトリックスの欠如が, 植生遷移の進行を著しく遅らせているのだと考え ている。マトリックスを欠く礫地は水分条件が悪 く，また発芽したり，根をはったりするための土 袞物質も存在しないから, 種子の発芽や幼芽の生 育は困難である。したがってシダ類や種子植物の ような高等な植物が礫地に定着するためには，ま ずマトリックスが㗂間を充填することが必要であ るが，この条件は節理岩地域では簡単には整わな い。マトリックスが砂間を埋めるためには, 岩石 の風化が進んで細か、鉱物粒子が供給されたり， 植物の破片が飛ばされてきて腐ったり，ごく稀な 事件だと思われるが，火山灰の供給があったりす ることが必要である。したがってこうした条件が
整うまでは, 礫地に侵入できるのは地衣類や蘚苔 類に限られたと思われる。おそらくこれらが分布 をしだいに桩大していく間に，岩屑の風化む進ん で，マトリックスも集積し，しだいに土壌が形成 されていくのであろう。これに要する時間牥数千 年から 1 万年程度といらことだと思われる。前記 Matthews (1992) も，マトリックスが欠如した場 合は，遷移の進行に要する時間は 1 析おおきくな り，1,000年以上かかると述べている。逆に，マ トリックスさえあれば植物の侵入は予想以上に簡 単で, 遷移の進行も速いように思われる。たとえ ば，カール内に崖錐がよく発達する北アルプス槍 ケ岳では，口絵 2-10 に示したように細かい岩屑 が上部から供給される現成の崖錐上に，すでに高 等植物からなる植物群落が発達しているのである。 マトリックスの重要性を確かめるためには, 高 等植物を欠く碑地にマトリックスを人為的に補い, その後の植物の侵入の状況を調べるという実験を 行なってみるのも一つの試みとして有力なもので あろう。これはいずれ実施してみたいと考えてい る。

なお上記の植生の発達に要する年代の值は, 先 に紹介した薬師岳の場合（小泉，1989）とほぼ調 和的である。節理岩地域における植生遷移の速さ と, 薬師岳における植物群落の発達はほぼ平行し ている。

\section{IV. まとめ}

1. 北アルプス白馬岳北方の節理岩と仮称して いる一帯では，花崗斑岩という同一の地質地域に ありながら種組成を著しく異にする植物群落がみ られる。まず肩の部分には高等植物を欠き, 地衣 類がわずかに分布するだけの礫地がある（この礫 地を礫地 I と仮称)。ここでは地衣類は 12 種を 数 え, 蘚苔類も 1 種出現するが, いずれも分布はき わめて疎らである。砅地 I の下方には地衣類 21 種に加え，4種類の蘚苔類をもつ礫地がある（礫 地 II)。ここでは䃯地は全体として黒ずんでおり， 地衣類などの付着する度合も礫地 I よりはるかに 高い。一方, 節理岩の下方にはクロマメノキやミ ヤマダイコンソウ，ヒゲハリスゲなどからなる， 
風衝矮低木群落と風衝草原の混合群落が成立して おり，群落下には薄い高山草原土壤があって植被 率は60～70\%に達している（磦地III）。この群落 の下方はハイマツ群落に移行する。

2. 各礫地はほとんど稜線近くの強風地に位置 しているから，気候条件にはほとんど違いは認め られない。またいずれの䃯地もマトリックスを欠 いていて，土地条件には著しい差はない。したが って群落組成の違いをこれらの条件に求めること は困難である。本研究では, 群落の違いはこの場 所での植生遷移の段階の違いを示しているのでは ないかと考え，䃯に生じた風化皮膜を用いて，各 礫地を構成する礫の供給期を推定することを試み た。礫地 I， II， III における風化皮膜の厚さは, 平均してそれぞれ $1.1 \mathrm{~mm}, 2.1 \mathrm{~mm}, 4.1 \mathrm{~mm}$ で, これらから推定される岩原供給期（=斜面形成 期）は次のようである。

礫地 I：ネオグラシエーション期

碖地 II：晚水期

搖地 III : 最終氷期最盛期

3. これに基づいて節理岩の高山帯強風地での 植物群落の発達に要する時期を考えると, 3,000 年ほどかかって疎らな地衣類からなる群落，1万 年程度かかって地衣類と蘚苔類の混合した群落が でき，さらに数千年かかってようやく風衝矮低木 群落や風衝草原といった発達した群落ができ, 土 㙵層も形成されることになる。植生遷移の進み方 はきわめて遅いが，マトリックスの欠如がその主 要因になっていると考える。

\section{V. おわりに}

筆者は数年前, 薬師岳に㧍ける高山植物群落の 成立条件について論じ（小泉，1989）, 地質によ って斜面の形成期が異なるために，地質ごとに植 物群落の発達度合にも違いが出てくるという事例 を明らかにした。本論文ではこれをさらに一歩進 め, 同一の地質地域でも岩屑の供給期が何回かに 分かれることがあるといらことを明らかにし，そ れに基づいて植生遷移の様式と速さを導いた。

本文中でも述べたように, 北アルプス節理岩地 域の花崗斑岩砂地に抢ける, 推定された遷移のス
ピードは著しく遅いものである。おが国の高山带 で植生遷移の速さを実際に提出したのはおそらく 本論文が初めてだと思うが，同じ視点から各地の 高山植物群落を見直してみれば，似たような事例 が多数現われるのではないかと予想している。本 研究の当否を点検するためにも, 高山帯の植物群 落を研究しておられる方々には, この種の研究に もぜひ手を染めていただきたいと考える。

また今回報告したような地衣類や蘚苔類しか分 布しない礫地は, 高等植物を欠くために, 植物生 態学者の研究対象としてはこれまで見過ごされて きたのではないかと思う。今後, 地衣類などの專 門家による調査を期待したい。ハイマツ群落や風 衝草原・風衝矮低木群落などに関しても, 従来は これらが高山帯や強風地の極相植生であることを 疑う人はいなかったが，もしかしたらまだ遷移の 途中にある群落であるかもしれない。この点に関 しても再検討をお願いしたいと思う。

\section{文献}

岩田修二 (1980): 白馬岳の砂碟斜面に働く地形形成作 用一一移動様式とその強度. 地学雑誌, 83, 319-335. 小泉武栄 (1979): 高山の寒冷気候下における岩屑の生 産・移動と植物群落 I. 白馬山系北部の高山荒原植物 群落. 日本生態学会誌, 29,71-81.

小泉武栄 (1980)：高山の寒冷気候下に打ける岩屑の生 産・移動と植物群落 III. 北アルプス北部鉢ケ岳付近 の花菵斑岩地及び古生界砂岩・頁岩地の風衝植物群落. 日本生態学会誌, 30, 173-181.

小泉武栄 (1989): 北アルプス薬師岳における 斜面発達 々強風地植物群落. 日本生態学会誌, 39, 127-137.

小泉武栄・青柳章一 (1993) : 風化被膜から推定した 北 アルプス薬師岳高山带に押ける岩屑の供給期. 地理学 評論, $66 \mathrm{~A}, 269-287$.

小泉武栄・関 秀明 (1988): 高山地域における最終水 期以降の岩屠生産と斜面形成. 文部省科学研究費補助 金総合研究 (A) 研究成果報告書「日本における沖積 平野・沖積層の形成と第四紀末期の自然環境とのかか わりに関する研究」(代表 : 井関弘太郎)，93-107.

高山地形研究グループ (1978) : 白馬岳高山帯の地形と 植生. 寒冷地形談話会, $164 \mathrm{p}$.

Matthews, J. A. (1992): The ecology of recentlydeglaciated terrain. A geoecological approach to glacier foreland and primary succession. Cambridge University Press, Cambridge, $386 \mathrm{p}$.

水野一睛 (1989): 北アルプス三ツ岳周辺の風衝地にお ける斜面構成物質との関係からみた高山植物の立地.

日本生態学会誌, 39, 97-105. 
水野一晴 (1994) : ケ二ヤ山, Tyndall 水河の後退過程 と植生の遷移およびその立地条件. 地学雑誌， 103, 16-29.

相馬秀広・岩田修二・岡沢修一（1979）：白馬岳高山帯
における砂礫の移動プロセスとそれを規定する要因. 地理学評論, 52, 562-579.

(1994年10月 21 日受付，1995年 5 月15日受理） 